\title{
HUBUNGAN ANTARA RELIGIUSITAS DAN REGULASI EMOSI DENGAN PERILAKU PROSOSIAL PADA REMAJA DI SMK KETINTANG SURABAYA
}

\author{
Khoirotus Silfiyah ${ }^{1}$, Suroso $^{2}$, Amanda Pasca Rini ${ }^{3}$ \\ Universitas 17 Agustus 1945 Surabaya \\ Email: silfiyahsania@gmail.com
}

\begin{abstract}
This study aims to know the relationship between religiosity and emotional regulation towards prosocial behavior in adolescents. The subject of the study is 107 adolescents from SMK Ketintang Surabaya, ranging between the ages of 15-18 years old. Using regression analysis, the result shows the existence of relationship between religiosity, emotional regulation, and prosocial behavior (Freg $=36.108 ; p=0.001<0.01)$; and also of positive relationship between religiosity towards prosocial behavior ( $t$ reg $=5.561 ; p=0.001<0.01$ ); as well as the positive relationship between emotional regulation towards prosocial behavior ( $t$ reg $=$ 2.348; $p=0.021<0.05$ ).
\end{abstract}

Keywords: Religiosity, Emotional Regulation, Prosocial Behavior

\section{Pendahuluan}

Budaya Indonesia terkenal dengan sikap gotong royong dan saling membantu dalam kehidupan sehari-hari. Mengingat bahwa pada dasarnya manusia adalah makhluk sosial yaitu saling membutuhkan antara manusia yang satu dengan yang lainnya. Perilaku saling membantu perlu dimiliki oleh setiap manusia khususnya remaja. Masa remaja merupakan masa pencarian identitas. Identitas yang dicari oleh remaja yaitu berusaha menjelaskan siapa dirinya dan peranannya dalam masyarakat (Hurlock, 2003). Agar peranannya dapat diterima oleh masyarakat, remaja diharapakan memiliki perilaku prososial yang baik. Perilaku prososial memegang peran yang penting bagi remaja, karena pada dasarnya manusia merupakan makhluk sosial yang membutuhkan bantuan dari orang lain, begitu juga sebaliknya. Menurut Taylor dkk (2009) perilaku prososial merupakan perilaku menguntungkan dan dilakukan untuk menolong orang lain tanpa memperdulikan motif-motif penolong. Perilaku prososial bermanfaat dalam masyarakat karena salah satu bagian dari interaksi sosial.

Faktanya saat ini perilaku prososial dikalangan remaja semakin menurun. Berdasarkan hasil wawancara dengan guru BK pada tanggal 26 November 2018 di salah satu sekolah swasta di Surabaya menjelasakn bahwa saat ini terlihat perilaku siswa-siswa yang menurun dalam hal tolong menolong. Hal ini terlihat dari sikap siswa yang mulai acuh dan pasif dengan lingkungannya. Guru BK menjelaskan bahwa pada kelas X terlihat siswa-siswa menunjukkan perilaku prososialnya kepada teman sekelas contohnya ketika ada temannya tidak membawa buku pelajaran atau pensil, maka teman sekelas akan segera meminjamkannya kepada teman 


\section{Khoirotus Silfiyah}

tersebut. Berdasarkan hasil observasi pada tanggal 27 November 2018 yaitu ketika ada guru terlihat kewalahan saat membawa buku atau membawa barang, para siswa terlihat abai dan tidak menawarkan diri untuk membantu. Selain itu ketika melihat temannya terpeleset, sebagian dari siswa-siswi malah menertawakan dan tidak segera membantu.

Hasil wawancara pada tanggal 28 November 2018 dengan beberapa siswa menunjukkan bahwa mayoritas siswa akan memberikan bantuan apabila mengenal orang yang akan ditolong, apabila dengan orang lain yang tidak dikenalnya, siswa cenderung enggan dan takut untuk menolong. Menurunnya kepekaan siswa menyebabkan siswa menjadi acuh tak acuh dan bahkan tidak peduli terhadap kehidupan lingkungan sekitar. Hal ini tentunya bertentangan dengan ciri bangsa Indonesia yang memiliki kepekaan sosial yang tinggi dalam segala hal. Untuk mencapai suatu tujuan dibutuhkan adanya kerja sama dari lingkungan sekitar. Oleh karena itu, perilaku prososial perlu dikembangkan dalam kehidupan sehari-hari.

Data hasil wawancara pada 28 November 2018 dengan guru yaitu mayoritas siswa merupakan anak-anak yang memiliki pengetahuan agama yang kurang matang, sehingga dalam kesehariannya siswa kurang dapat mengaplikasikan pengetahuan tentang agamanya dengan cukup baik. Keterangan dari guru kelas mengatakan bahwa siswa-siswa belum menjalankan solat dengan tertib. Berdasarkan hasil observasi, saat watu solat telah tiba mayoritas siswa tidak segera pergi ke musholla untuk melaksanakan solat, siswa-siswi justru pergi ke kantin untuk membeli makanan dan ada beberapa yang mengobrol dan bermain handphone dan tidur di dalam kelas.

Menurut Myer (dalam Muryadi \& Matulessy, 2012) salah satu faktor yang mempengaruhi perilaku prososial adalah religi. Miftah dan Ritandiyono (dalam Jamaluddin, 2016) mengasumsikan bahwa apabila remaja memiliki religiusitas rendah, tingkat kenakalan cenderung tinggi dan perilaku tidak sesuai dengan agama. Begitu juga sebaliknya, semakin tinggi religiusitas, semakin rendah tingkat kenakalan remaja. Hal ini berkaitan juga ketika remaja memiliki religiusitas tinggi, maka remaja akan melakukan perilaku prososial.

Artinya, remaja berusaha berperilaku sesuai dengan agama yang dianutnya karena memandang agama sebagai tujuan hidunya sehingga berusaha menginternalisasikan ajaran agama dalam perilaku sehari-hari. Hal ini dikarenakan agama mendorong para pemeluknya untuk berperilaku baik dan bertanggungjawab atas perbuatannya, dan menganjurkan berlombalomba dalam kebajikan. Seperti bersikap baik dan ramah kepada guru/teman, menolong teman yang membutuhkan bantuan, gotong royong dalam kegiatan sosial/kerja bakti, berkata dan bertindak jujur, berbagi buku pelajaran apabila teman sebangku lupa tidak membawa dan berbagi pengetahuan dan lain-lain. 
Senada dengan penelitian Muryadi \& Matulessy (2012) yang membahas tentang religiustas, kecerdasan emosi, dan perilaku prososial guru. Hasil penelitian menunjukkan adanya hubungan positif antara religiusitas dan perilaku prososial, artinya semakin tinggi religiusitas, semakin tinggi perilaku prososial.

Berdasarkan data yang peneliti dapatkan dari guru BK mengatakan bahwa siswa-siswi masih kurang dalam mengendalikan dan mengarahkan emosi dengan baik. Hal ini ditunjukkan dengan sikap siswa-siswi yang mudah terpancing emosinya saat dihadapkan dengan situasi tertentu. Contohnya saat ada salah satu siswa saat berjalan tidak sengaja menyenggol teman kelas, dengan segera dari mereka mengatakan hal yang buruk sehingga timbul perkelahian antar kelas.

Menurut Rosenblum \& Lewis (dalam Santrock, 2007) masa remaja merupakan masa "badai dan stres" yaitu suatu masa dimana remaja mengalami fluktuasi emosi (naik dan turun) berlangsung lebih sering. Steinberg \& Levine (dalam Santrock, 2007) mengemukakan bahwa remaja mudah merasa bahagia pada suatu kondisi tertentu dan kemudian merasa sebagai orang yang paling malang pada kondisi saat lain. Agar remaja tetap mampu mempertahankan emosinya, maka remaja diharapkan memiliki kemampuan dalam mengelola emosinya. Kemampuan mengelola atau mengendalikan emosi disebut regulasi emosi. Regulasi emosi memiliki arti sebagai pembentukan emosi seseorang, emosi yang dimiliki, dan pengalaman atau bagaimana seseorang mengekspresikan emosi tersebut. Regulasi emosi berkaitan dengan bagaimana emosi itu di atur, bukan bagaimana emosi mengatur sesuatu yang lain (Gross, 2014).

Taylor dkk (2009) mengemukakan bahwa perilaku prososial merupakan tindakan yang dilakukan untuk menolong orang lain, terlepas dari motif penolong. Individu yang memiliki religiusitas yang baik, akan tersentuh hatinya untuk menolong siapapun yang membutuhkan pertolongan. Hal tersebut dilakukan karena suatu bentuk dari ajaran agama. Sebagaimana yang dikemukan oleh Glock \& Stark (1965) bahwa dalam religiusitas terdapat lima dimensi yaitu dimensi kepercayaan, dimensi praktek atau ritual, dimensi pengalaman, dimensi pengetahuan dan intelektual, serta dimensi konsekuensi. Dalam hal ini religiusitas memiliki pengaruh terhadap perilaku prososial karena tindakan menolong merupakan suatu bentuk ketaatan seseorang pada agamanya.

Remaja yang memiliki religiusitas tinggi, akan menunjukkan perilaku prososial yang tinggi pula seperti bersedia berbagi dalam keadaan suka maupun duka, bekerja sama dalam mencapai tujuan, menolong teman-teman tanpa pandang bulu, bersedia mengatakan yang sebenarnya segala sesuatu yang sudah dilakukan, dan bersedia menyumbangkan barang 


\section{Khoirotus Silfiyah}

maupun uang kepada orang yang benar-benar membutuhkan, sebaliknya jika remaja memiliki tingkat religiusitas yang rendah maka remaja cenderung tidak peduli dengan lingkungan sekitar dan bahkan berperilaku yang melanggar aturan yang ada dimasyarakat. Begitu juga ketika remaja memiliki regulasi emosi yang baik, maka remaja mampu berperilaku prososial dengan baik seperti memberikan pertolong kepada teman bagaimanapun kondisinya, menghibur dan memberikan dukungan kepada teman, karena remaja mampu mengendalikan dan mengatur emosinya dengan baik seperti mampu menahan emosinya ketika dalam keadaan marah dan mampu mengekspresikan emosinya secara positif.

\section{Perilaku Prososial}

Perilaku menolong juga kerap kali disebut altruisme, akan tetapi altruisme yang sebenarnya merupakan tindakan menolong yang mementingkan orang lain dan mengabaikan diri sendiri. Menurut Widyastuti (2014) perilaku prososial mencakup kategori yang lebih luas, segala bentuk tindakan yang dilakukan atau direncanakan untuk menolong orang lain, tanpa memperdulikan motif-motif penolong. Taylor dkk (2009) mengemukakan bahwa perilaku prososial merupakan perilaku yang menguntungkan dan dilakukan untuk menolong orang lain tanpa memperdulikan motif penolong. Perilaku prososial sangat bermanfaat dalam masyarakat karena salah satu bagian dari interaksi sosial. Lebih lanjut William (dalam Dayakisni \& Hudaniah, 2009) memberikan penjelasan bahwa perilaku prososial adalah perilaku mengubah fisik atau psikologis orang lain yang kurang menguntungkan menjadi lebih menguntungkan, sehingga penolong merasa bahwa penerimaan menjadi lebih sejahtera atau bahagia secara materi maupun psikologis.

Berdasarkan pengertian prososial di atas, dapat disimpulkan bahwa perilaku prososial merupakan suatu tindakan yang positif dan menguntungkan secara fisik maupun psikis bagi orang orang lain terlepas dari motif-motif penolong.

Menurut Myer (dalam Widyastuti, 2014) terdapat tiga norma penting dalam perilaku prososial yaitu norma tanggung jawab sosial, norma timbal balik, dan norma keadilan sosial. Menurut Widyastuti (2014) terdapat tiga faktor penentu dalam perilaku prososial yaitu (1) faktor situasi yang meliputi kehadiran orang lain, sifat lingkungan, fisik, dan tekanan keterbatasan waktu, (2) Karakteristik penolong meliputi faktor kepribadian, suasana hati, rasa bersalah, distres diri (reaksi pribadi kita terhadap orang lain-perasaan terkejut, cemas, takut, prihatin, tidak berdaya), serta sikap empatik (perasaan simpati dan perhatian terhadap orang lain), dan (3) Karakteristik orang yang membutuhkan pertolongan, misalnya menolong orang yang kita sukai dan menolong orang yang pantas untuk ditolong. 


\section{HUBUNGAN ANTARA RELIGIUSITAS DAN REGULASI EMOSI}

Mussen dkk (dalam Nashori, 2008) mengemukakan beberapa aspek-aspek yang terdapat pada perilaku prososial yaitu sharing (berbagi), cooperating (bekerjasama), helping (menolong), donating (donasi/berderma), dan honesty (jujur).

\section{Religiusitas}

Menurut Nasution (dalam Djamaluddin, 2004) pengertian agama ialah berasal dari kata Al-Din yang artinya undang-undang atau hukum. Selanjutnya, dalam kamus bahasa Arab memiliki arti menguasai, tunduk, patuh, utang, balasan, dan kebiasaan.

Secara harfiah agama merupakan sebuah aturan atau tata cata hidup manusia yang dipercayainya dan bersumber dari Tuhan Yang Maha Esa untuk kebahagian di dunia maupun di akhirat. Glock \& Strack (dalam Ancok \& Suroso, 2004) mengartikan agama atau religiusitas sebagai sebuah sistem simbol, sistem keyakinan, sistem nilai, dan sistem perilaku yang terteta dan semua itu berpusat pada hal-hal yang dihayati dan bermakna (ultimate meaning). Menurut Thouless (2000) mendefinisikan agama sebagai sikap (atau penyesuaian diri) terhadap dunia yang menunjukkan lingkungan yang lebih luas jika dibandingkan dengan lingkungan fisik yang terikat ruang dan waktu the spatio temporal phsycal world (dalam hal ini adalah dunia spiritual). Selanjutnya, menurut Shihab (dalam Nashori \& Mucharam, 2007) agama adalah ketetapan Illahi yang diwahyukan kepada Nabi-Nya untuk menjadi panutan hidup bagi manusia.

Religiusitas yaitu mengacu pada tingkat keterikatan individu terhadap agamanya. Aktivitas dalam agama tidak hanya terjadi ketika individu melakukan ritual (ibadah), akan tetapi ketika melakukan segala kegiatan yang didorong oleh kekuatan supranatural. Selain itu, tidak hanya kegiatan yang tampak dan dapat dilihat oleh panca indera, namun kegiatan yang tidak tampak dan terjadi di dalam hati (Ghufron \& Risnawita, 2011).

Berdasarkan penjelasan di atas, dapat disimpulkan bahwa religiusitas merupakan nilainilai dalam agama yang wajib dipatuhi dan dihayati bagi pemeluknya baik secara fisik maupun psikis yang didalamnya mencakup kegiatan ibadah dan kaidah-kaidah agama.

Glock \& Stark seperti yang dikutip oleh Ancok dan Suroso (2004) mengemukakan terdapat lima dimensi keberagamaan yaitu dimensi keyakinan, dimensi agama (ritualistic dimension), dimensi ihsan/penghayatan, dimensi pengetahuan agama, dan dimensi pengalaman/konsekuensi. Kelima dimensi merupakan satu kesatuan yang saling mempengaruhi satu sama lain dalam memahami religiusitas. Thouless (2000) membedakan faktor-faktor yang mempengaruhi keberagamaan menjadi empat yaitu pengaruh pendidikan atau pengajaran dari berbagai tekanan sosial (faktor sosial), berbagai pengalaman yang 


\section{Khoirotus Silfiyah}

membantu sikap keagamaan, terutama pengalaman-pengalaman (keindahan, keselarasan, pengalaman emosional keagamaan, konflik moral), faktor-faktor yang seluruhnya atau sebagian timbul dari kebutuhan-kebutuhan yang tidak terpenuhi, terutama kebutuhankebutuhan terhadap keamanan, cinta kasih, harga diri, dan ancaman kematian, dan Berbagai proses pemikiran verbal (faktor intelektual).

\section{Regulasi Emosi}

Konsep pertama tentang regulasi emosi dikemukakan oleh Thompson (1994) menjelasakan pengertian sederhana bahwa regulasi emosi merupakan kemampuan mengontrol emosi dan perilaku sebagai cara mengekspresikan emosi agar sesuai dengan lingkungan di sekitarnya. Lebih lanjut Thompson (1994) mengartikan bahwa regulasi emosi adalah serangkaian proses intrinsik dan ekstrinsik yang bertanggung jawab untuk memantau, mengevaluasi dan memodifikasi reaksi emosional, terutama elemen temporal dan intensitasnya untuk mencapai tujuan. Karakteristik regulasi emosi yaitu mampu menghambat, mempertahankan, meningkatkan emosi negative, mengatur emosi yang berasal dari luar, dan regulasi emosi berfungsi mengatur tujuan hidup ketika dihadapkan dengan berbagai kondisi.

Gross (1998) menjelaskan bahwa regulasi emosi mengacu pada proses-proses yang dilakukan seseorang untuk mempengaruhi emosi mereka, dan bagaimana mereka mengalami dan mengekspresikan emosi tersebut. Proses regulasi emosi dapat otomatis atau dikendalikan, sadar atau tidak sadar, dan dapat memberi efek pada satu atau lebih inti dalam proses emosi secara keseluruhan. Gross (1998) menjelaskan pengertian regulasi dalam lima hal, pertama regulasi emosi individu berkaitan dengan proses meningkatkan, mempertahankan, dan menurunkan emosi negatif atau emosi positif. Gross dan John (2004) menjelaskan strategi regulasi emosi yang digunakan seseorang terdiri dari dua cara yakni reappraisal dan suppression. Reappraisal merupakan regulasi emosi dimana seseorang berpikir tentang situasi yang mengubah respon emosi. Suppression dimana seseorang menurunkan ekspresi emosi ketika dihadapkan dengan emosi arousal.

\section{Hipotesis}

Berdasarkan rumusan masalah dan landasan teori di atas, maka hipotesis yang diajukan dalam penelitian ini adalah : a) ada hubungan antara religiusitas \& regulasi emosi dengan perilaku prososial, b) ada hubungan positif antara religiusitas dengan perilaku prososial, c) ada hubungan positif antara regulasi emosi dengan perilaku prososial. 


\section{HUBUNGAN ANTARA RELIGIUSITAS DAN REGULASI EMOSI}

\section{Metode Penelitian}

Penelitian ini menggunakan penelitian kuantitatif yang bersifat korelasional dengan menggunakan variabel bebas religiusitas dan regulasi emosi dengan variabel terikat adalah perilaku prososial. Sampel yang digunakan dalam penelitian ini adalah simple random berjumlah 107 remaja siswa dengan perbedaan umur di SMK Ketintang Surabaya baik lakilaki maupun perempuan. Pengambilan sampel dalam penelitian ini menggunakan sampel secara acak (random sampling). Hasil uji reliabilitas skala perilaku prososial dalam penelitian ini diperoleh koefisien reliabilitas sebesar 0,868, sedangkan hasil uji coba skala religiusitas dalam penelitian ini diperoleh koefisien reliabilitas sebesar 0,902 menggunakan perhitungan SPSS 20.0.

\section{Hasil}

Data yang telah terkumpul dan sudah dilakukan beberapa uji diskriminasi item, uji reliabilitas, uji prasayarat (uji normalitas sebaran dan uji linearitas hubungan) sebagai prasyarat dalam melakukan analisis data. Hipotesis dalam penelitian ini diuji dengan menggunakan analisis regresi. Perhitungan analisis data menggunakan SPSS versi 20.0, sehingga hasilnya dapat dilaporkan sebagai berikut:

1. Hipotesis pertama, adanya hubungan antara religiusitas dan regulasi emosi terhadap perilaku prososial. Uji hipotesis dilakukan menggunakan regresi ganda untuk membuktikan hipotesis bahwa variabel religiusitas dan regulasi emosi secara bersamasama berhubungan dengan perilaku prososial. Hasil analisis yang telah dilakukan menghasilkan nilai $F$ hitung sebesar 36,108 dan nilai signifikansi sebesar $\mathrm{p}=0,000$ $(\mathrm{p}<0,05)$. Hasil ini mengindikasikan bahwa variabel religiusitas (X1) dan regulasi emosi (X2) bersama-sama berhubungan sangat signifikan dengan perilaku prososial pada siswa di Sekolah SMK Ketintang Surabaya. Sumbangan efektif yang diberikan oleh variabel religiusitas dan regulasi emosi terhadap perilaku prososial adalah sebesar R-Square 0,410 (41\%).

2. Hipotesis kedua yang berbunyi terdapat hubungan positif antara religiusitas dengan perilaku prososial. Hasil analisis yang telah dilakukan menghasilakn nilai t regresi sebesar 5,561 dan nilai signifikansi sebesar $\mathrm{p}=0.001(\mathrm{p}<0,01)$, maka terdapat hubungan yang sangat signifikan dan hipotesis dinyatakan diterima. Artinya, semakin tinggi religisuitas remaja, maka semakin tinggi perilaku prososial.

3. Hipotesis ketiga yang berbunyi terdapat hubungan positif antara regulasi emosi dengan perilaku prososial. Hasil analisis yang telah dilakukan menghasilkan nilai t regresi 


\section{Khoirotus Silfiyah}

2,348 dan nilai signifikansi sebesar $\mathrm{p}=0,021(\mathrm{p}<0,05)$, maka terdapat hubungan yang sangat signifikan dan hipotesis dinyatakan diterima. Semakin tinggi kemampuan remaja dalam meregulasi emosinya, maka semakin tinggi perilaku prososialnya.

\section{Pembahasan}

Hasil uji hipotesis pertama menunjukkan bahwa terdapat hubungan yang signifikan antara religiusitas \& regulasi emosi dengan perilaku prososial, artinya kedua prediktor yaitu religiusitas dan regulasi emosi menunjukkan secara bersama-sama hubungan yang positif terhadap perilaku prososial. Religiusitas dapat dilihat melalui lima dimensi. Pertama, dimensi keyakinan adalah sejauh mana seseorang menerima dan mengetahui hal-hal yang dogmatik dalam agama meliputi keyakinan tentang sifat-sifat Tuhan, percaya dan yakin dengan ke-Esaan Tuhan, adanya malaikat, kitab-kitab, para nabi, dan lain sebagainya. Kedua, dimensi peribadatan atau praktik agama yaitu melihat sejauh mana individu melaksanakan kewajibankewajiban dalam agamanya seperti menjalankan ibadah, berdo'a, puasa, zakat, dan lain-lain. Ketiga, dimensi penghayatan yaitu perasaan keagamaan yang pernah dirasakan seperi merasa dekat dengan Tuhan, merasa bahwa Tuhan selalu menjaganya, merasa tenang dan tentram saat mendengar atau membaca kitab suci, dan merasa do'a-do'anya dikabulkan oleh Tuhan. Dimensi keempat, pengetahuan agama adalah seberapa jauh seseorang mengetahui dan memahami ajaran-ajaran agama terutama yang ada dalam kitab suci, hadits, tentang fikih, buku-buku agama dan lain-lain. Dimensi kelima, dimensi pengalaman atau konsekuensi adalah sejauh mana implikasi ajaran agama mempengaruhi perilaku seseorang dalam kehidupan sosial. Misalnya mendermakan harta untuk keagamaan, menjenguk orang sakit, memberikan bantuan dan pertolongan kepada orang yang membutuhkan, mempererat silaturrahim dan tindakan positif lainnya.

Hasil penelitian ini mendukung penelitian sebelumnya oleh Muryadi \& Matulessy (2012) meneliti tentang religiusitas, kecerdasan emosi, dan perilaku prososial pada guru. Hasil penelitian menunjukkan adanya hubungan positif antara religiusitas dan perilaku prososial, artinya semakin tinggi religiusitas, semakin tinggi perilaku prososial, demikian sebaliknya. Hal ini sesuai dengan pendapat Myer (dalam Widyastuti, 2014) bahwa terdapat salah satu norma dalam perilaku prososial yaitu adanya tanggung jawab sosial yang mana di dalamnya mencakup aturan agama dan moral. Agama pada dasarnya menganjurkan untuk saling tolong menolong. Maka, melalui agama remaja akan bersikap dan berperilaku prososial seperti sukarela berbagi dalam keadaan suka maupun duka melalui dukungan verbal maupun fisik, memberikan bantuan kepada orang yang membutuhkan, bekerjsama untuk mencapai tujuan, 


\section{HUBUNGAN ANTARA RELIGIUSITAS DAN REGULASI EMOSI}

menolong atau menawarkan bantuan kepada orang lain untuk meringankan beban, dan berkata jujur dan apa adanya. Remaja yang memiliki religiusitas yang baik, maka ia akan menggunakannya sebagai pedoman dalam bersikap dan berperilaku dalam masyarakat. Tidak hanya itu, remaja juga akan mengimplikasikan segala pengetahuan tentang ajaran agamanya dalam setiap tujuannya, akan tetapi jika remaja tidak menggunakan agama sebagai pedoman hidupnya, maka remaja akan mudah terpengaruh dengan hal-hal yang negatif bahkan melanggar norma yang ada dilingkungannya.

Santrock (2007) menjelaskan regulasi emosi adalah kemampuan individu untuk mengatur rangsangan (misalnya kemarahan) dalam rangka beradaptasi dan meraih suatu tujuan secara efektif. Teori tersebut mendukung penelitian dilakukan oleh Rochmah (2018) peran regulasi emosi dan pengasuhan ototitatif seorang ibu terhadap perilaku prososial di media sosial pada remaja. Hasil penelitian menunjukkan bahwa regulasi emosi merupakan faktor yang mempengaruhi perilaku prososial. Hal ini dikarenakan perilaku prososial sangat berkaitan dengan adanya emosi, sehingga regulasi emosi berfungsi untuk mengendalikan dan mengatur emosi yang diekspresikan baik positif maupun negatif ketika dihadapkan pada situasi maupun kondisi yang menantang, menyenangkan, maupun kurang menyenangkan.

Remaja yang memiliki regulasi emosi yang baik, maka remaja mampu berperilaku prososial misalnya dalam keadaan senang atau maupun sedih memiliki keinginanan untuk memberikan bantuan kepada orang lain, tetap berkata jujur, menawarkan bantuan kepada teman. Sebaliknya jika remaja memiliki regulasi emosi yang rendah, maka remaja cenderung menghindari untuk memberikan atau menawarkan bantuan kepada orang lain.

Diterimanya hipotesis kedua dalam penelitian yaitu terdapat hubungan antara religiusitas dengan perilaku prososial. Religiusitas menunjukkan pada tingkat keterikatan atau ketundukan individu terhadap agama yang dianutnya. Drajat (Ghufron dan Risnawita, 2011) mengemukakan bahwa agama meliputi kesadaran beragama dan pengalaman beragama. Kesadaran beragama merupakan aspek yang terasa dalam pikiran dan merupakan aspek mental dari aktivitas beragama, sedangkan pengalaman beragama adalah perasaan yang membawa kepada keyakinan yang dihasilkan oleh tindakan.

Individu dikatakan memiliki religiusitas baik apabila tidak hanya mengetahui tentang agamanya dan ajaran-ajarannya, akan tetapi mampu memahami dan mengaplikasikan dalam kehidupan sehari-hari. Religiusitas individu dapat dilihat dari beberapa dimensi yang dikemukan oleh Glock dan Starck (dalam Ancok \& Suroso, 2004) pertama, dimensi keyakinan yakni melihat sejauh mana seseorang menerima dan mengakui doktrin agama yang meliputi keyakinan atau kepercayaan terhadap Tuhan, sifat-sifat Tuhan, adanya utusan atau Nabi, 


\section{Khoirotus Silfiyah}

percaya adanya surga dan neraka serta ganjaran baik atau buruk atas perilaku yang dilakukan. Kedua dimensi praktik agama yaitu melihat sejauh mana seseorang dalam menjalankan kewajiban dalam ritual dalam agamanya. Misal berdoa, membaca Al-Qur'an/Al-kitab, pergi ke masjid bagi agama muslim dan ke gereja bagi agama Kristen/katolik, puasa dan lain-lain.

Ketiga, dimensi penghayatan yang berhubungan dengan perasaan dekat dengan Tuhan, merasakan kedamaian dan ketentraman dalam berdoa, merasakan nikmat atas anugerah yang diberikan dan sebagainya. Keempat dimensi pengetahuan agama yaitu mengetahui sejauh mana seseorang dalam memhami ajaran tentang agama yang dianutnya terutama yang ada pada kitab suci, fiqih, akidah dan sebagainya. Kelima yaitu dimensi pengalaman atau konsekuensi yaitu sejauh mana seseorang mengimplikasikan ajaran agama sehingga mempengaruhi perilaku dalam kehidupan sehari-hari seperti beramal/berdonasi, menjenguk orang sakit, saling tolong menolong, ramah kepada semua orang, dan mempererat silaturrahim.

Sebagaimana dijelaskan bahwa religiusitas seseorang dilihat dari sejauh mana seseorang mengimplikasikan ajaran agama dalam kehidupan sehari-hari salah satunya yaitu mengajarkan untuk tolong menolong dan ramah kepada semua orang. Sejalan dengan pendapat Myer (dalam Muryadi \& Matulessy, 2012) mengatakan bahwa religi selain sebagai faktor yang berpengaruh dalam membentuk perilaku menolong, juga menjanjikan perlindungan dan rasa aman bagi seseorang untuk menemukan eksistensi dirinya. Karena pada dasarnya agama mengajarkan untuk saling tolong menolong dalam hal-hal kebaikan. Penelitian Saroglou dkk (dalam Stamatoulakis, 2013) mengemukakan bahwa reigiusitas berpengaruh pada perilaku prososial. Saroglou mengatakan bahwa ketika indivdu benar-benar religius, mereka cenderung terlibat dalam perilaku prososial, lebih berempati, dan bersedia mengikuti pedoman moral sesuai dengan agama. Selain itu penelitian yang dilakukan oleh Bernt \& Hansen (dalam Hardy \& Carlo, 2005) bahwa perilaku prososial atau altruism dipengaruhi oleh faktor religiusitas. Hal ini menunjukkan bahwa religiusitas sangat berhubungan dengan perilaku prososial. Semakin tinggi religiusitas maka, semakin tnggi perilaku prososial yang dilakukan sepertti saling berbagi dalam keadaan suka maupu duka, saling membantu baik secara materi maupun dukungan, saling tolong menolong kepada seseorang yang membutuhkan, berdonasi atau memberikan sebagian barang yang dimiliki kepada orang lain yang lebih membutuhkan, dan berkata jujur kepada diri sendiri maupun orang lain. Begitu pula sebaliknya, individu yang religiusitasnya rendah yaitu individu yang kurang memahami dan mengapilikasikan ajaran agamanya, sehingga inidvidu tersebut cenderung abai, kurang peduli dengan lingkungan 
sekitar, serta kurang tertarik dalam kegiatan sosial seperti kegiatan beramal/berdonasi atau gotong royong.

Diterimanya hipotesis ketiga dalam penelitian yaitu terdapat hubungan antara regulasi emosi dengan perilaku prososial. Dijelaskan oleh Eisenberg dkk (2006) bahwa peran emosi sangat penting dalam mengembangkan perilaku prososial. Remaja yang mampu meregulasi emosi dengan baik tentunya mampu dalam mengendalikan emosi yang ada pada dirinya baik emosi positif maupun negatif.

Penelitian yang dilakukan oleh Benita dkk (dalam Rochmah, 2018) menjelaskan bahwa secara langsung regulasi emosi mampu mempengaruhi perilaku prososial. Senada dengan penelitian Hein (dalam Rochmah, 2018) yaitu individu yang memiliki kemampuan dalam meregulasi emosi berhubungan dengan tingginya rasa empati dan perilaku prososial. Hasil penelitian tersebut menjelaskan bahwa ketika remaja memiliki kemampuan meregulasi emosi yaitu mengatur atau mengendalikan emosi negatif seperti rasa sedih, marah, kecewa, tertekan, dan terlalu membanggakan diri sendiri, mampu memfasilitasi emosi positif, maka pada akhirnya mempengaruhi perilaku prososial.

Adapun sumbangan efektif keduanya sebesar 41\%. Lebih rinci bahwasannya sumbangan efektif masing-masing variabel yaitu religiusitas terhadap perilaku prososial sebesar 30,77\%, sedangkan sumbangan efektif regulasi emosi terhadap perilaku prososial sebesar 10,23\%. Artinya masih ada 59\% faktor lain yang berhubungan sangat signifikan dengan perilaku prososial, namun faktor tersebut tidak diketahui dalam penelitian ini.

\section{Kesimpulan}

Berdasarkan hasil analisis regresi menunjukkan adanya hubungan yang sangat signifikan antara religiusitas dan regulasi emosi dengan perilaku prososial $(\mathrm{F}=36,108$ dan $\mathrm{p}<0,01)$. Kedua prediktor memberikan sumbangan $41 \%$ terhadap perilaku prososial. Maka, hipotesis pertama yang menyatakan terdapat hubungan antara religiusitas dan regulasi emosi dengan perilaku prososial di SMK Ketintang Surabaya diterima.

Berdasarkan hasil analisis korelasi parsial diperoleh data bahwa terdapat hubungan positif antara religiusitas dengan perilaku prososial ( $\mathrm{t}$ regresi $=5,561 \mathrm{dan} \mathrm{p}<0,01$ ). Artinya semakin tinggi religiusitas, semakin tinggi perilaku prososial. Sebaliknya, semakin rendah religiusitas, maka semakin rendah pula perilaku prososial. Maka, hipotesis kedua yang berbunyi terdapat hubungan antara religiusitas dengan perilaku prososial di SMK Ketintang Surabaya diterima. 


\section{Khoirotus Silfiyah}

Terdapat hubungan positif antara regulasi emosi dengan perilaku prososial ( $\mathrm{t}$ regresi $=2,348$ dan $\mathrm{p}<0,05)$. Artinya semakin tinggi regulasi emosi, maka semakin tinggi perilaku prososial. Maka, hipotesis ketiga yang berbunyi terdapat hubungan antara regulasi emosi dengan perilaku prososial di SMK Ketintang Surabaya diterima.

\section{Saran}

Berdasarkan hasil penelitian dan kesimpulan yang telah diuraikan, maka peneliti mengajukan beberapa saran sebagai berikut:

a. Bagi Subjek

Saran bagi subjek yaitu meningkatkan religiusitas dengan mengikuti kajian yang diselenggarakan oleh masyarakat, banyak membaca buku-buku agama, rutin mengikuti jama'ah sholat saat di sekolah, dan banyak membaca buku tentang agama. Sedangkan untuk meningkatkan regulasi emosi dengan konseling kelompok atau sosiodrama, dan pelatihan regulasi emosi.

b. Bagi Sekolah

Saran bagi sekolah yaitu menyelenggarakan kajian-kajian tentang keagamaan setiap minggu atau bulan, menyelenggarakan pelatihan regulasi emosi.

c. Bagi penelitian selanjutnya

Peneliti selanjutnya yang tertarik untuk melakukan penelitian yang sejenis dapat menjadikan penelitian ini sebagai acuan dan mengembangkan dengan menambahkan variabel lain yang mempengaruhi perilaku prososial yaitu pengasuhan orang tua, empati, moral, penggunaan media sosial.

\section{Daftar Pustaka}

Ancok, D \& Suroso. (2004). Psikologi Islam. Yogyakarta :Pustaka Belajar Dayaksini, T., \& Hudaniah. (2009). Psikologi Sosial. Malang: UMM Press.

Ghufron, N \& Risnawita, S. (2011). Teori-Teori Psikologi. Jogyakarta : Ar-Ruzz Media Gross, J. J. (2004). Handbook of regulation emotion second edition. New York: Guilford Press . (2003). Psikologi Perkembangan: Suatu Pendekatan Sepanjang Rentang Kehidupan. Edisi 5. Jakarta : Erlangga

Glock, C.,\& Stark, R. (1965). Religion and Society in Transition, Chicago: Rand Mc. Nally 
Hardy, S. A \& Carlo, G. (2005). Religiosity and prosocial behavioer in adolescence: the mediating role of prosocial values. Journal of moral education, 34 (2), 231-249

Jamaluddin, A. N. (2016). Dasar-dasar Patologi Sosial. Bandung: Pustaka Setia

Muryadi \& Matulessy, A. (2012). Religiusitas, kecerdasan emosi, dan perilaku prososial guru. Jurnal Psikologi 7(2) 554-561

Nashori, F \& Mucharam, R. D.(2002). Mengembangkan Kreativitas dalam Perspektif Psikologi Islami. Jogjakarta: Menara Kudus Jogjakarta

Nashori, F. (2008). Psikologi Sosial Islami. Bandung : Refika Aditama

Observasi di sekolah tanggal 27 November 2018

Rochmah, K. U. (2018). Peran regulasi emosi dan pengasuhan otoritatif ibu terhadap kecenderungan perilaku prososial di media sosial pada remaja. Tesis

Santrock, J. W. (2007). Adolescence, eleventh edition. Jakarta : Erlangga

Stamatoulakis, K. K. (2013). Religiosity and prosociality. Procedia social and behavioral sciences $82,830-834$

Taylor, S.E., Peplau, L. A., Sears, D. O. (2009). Psikologi Sosial. Edisi kedua belas. Depok : Prenadamedia Group

Thouless, R.H. (2000). Pengantar Psikologi agama. Jakarta: CV Rajawali Press.

Thompson, R. A. (1994). Emotion regulation: A theme in search of definition. monographs of the society for research in child development. 59 (2/3). 25-52

Widuri, E. L. (2012). Regulasi emosi dan resiliensi emosi pada mahasiswa tahun pertama. Humanitas, 9, 147-156.

Widyastuti. Y. (2014). Psikologi Sosial. Yogyakarta : Graha Ilmu

Yusuf, P. M., \&Kristiana, I. F. (2017). Hubungan antara regulasi emosi dengan perilaku prososial pada siswa sekolah menengah atas. Jurnal Empati 7 (3) 98-104

Wawancara Guru BK tanggal 26 November 2018

Wawancara Guru tanggal 28 November 2018

Wawancara Siswa tanggal 28 November 2018 